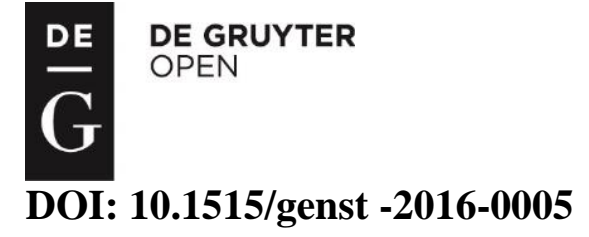

\title{
FEMININE HYPOSTASES IN EPIC FANTASY: TOLKIEN, LEWIS, ROWLING
}

\author{
LAURA MĂCINEANU \\ West University of Timişoara, Romania \\ 4, V. Pârvan Blvd, 300223 Timișoara, \\ laura_macineanu@yahoo.com
}

\begin{abstract}
The paper identifies the types of female figures present in the works of three well-known fantasy writers, J.R.R. Tolkien, C.S. Lewis and J.K. Rowling, discussing the ways in which these characters are presented, their relationship with other characters, and their role in the economy of the novel, which is more important than may appear from a first reading. It also tries to explain the reasons that prompted the above-mentioned authors to choose these female hypostases.

Keywords: archetypes, epic fantasy, feminine, gender, power
\end{abstract}

\section{Introduction}

The fact that women characters are scarce and stereotypical in works of epic fantasy has been reiterated in multiple articles and studies. However, there are many scholars, whose opinion I share, who recognise the important parts played within the story by these seemingly powerless/passive/submissive/one-dimensional women. Therefore, in this paper I will argue that, few in number as they may be, these female characters have a powerful presence and exercise a strong influence on other 
characters in the novels, often unexpectedly taking the lead and determining the course of action. The novels I will be referring to are J.R.R. Tolkien's The Lord of the Rings, The Chronicles of Narnia by C.S. Lewis and J.K. Rowling's Harry Potter series.

\section{Feminine hypostases and archetypes}

The female characters in the above-mentioned novels can relatively easily be assigned to one or another of the rather large array of archetypes already established via the work of such scholars as Jung, Joseph Campbell and their followers. Nevertheless, many of these characters transgress the limits of an archetype by developing and evolving, or have characteristics that belong to more than one archetype. In what follows I will refer to some of the most widely accepted character archetypes and identify the female figures in the works studied that belong to them; I will also analyse the way in which they match a specific archetype and demonstrate what makes them more complex than that.

\subsection{The Anima/the Holy Mother/the White Goddess}

This archetype finds its perfect embodiment in Galadriel, the Lady of Lothlórien. She fits the archetype both in her appearance, being a fair-haired woman of great, unearthly beauty, and in her spiritual power and religious connotations. Like Varda, High Queen of the Valars and Queen of Stars, and Yavanna, Queen of the Earth, she is a Marian representation in Tolkien's legendarium. Tolkien admitted that Galadriel possesses many of the attributes of the Virgin Mary, a figure so dear to Catholics. Galadriel enjoys not only spiritual power but also decision-making power in the Elven world; although she rules jointly with her husband, Celeborn, it is she who 
is the wiser and the more powerful, although they rule as equals. Adding to her status as Holy Mother is the fact that she is also a healer and comforter. She is a giver of gifts to the members of the Fellowship, gifts which will prove invaluable on their journey. Her comforting and encouraging presence is felt throughout the novel, whenever the members of the Fellowship are in need. However, in her youth Galadriel was the only woman to participate in the Elven rebellion against the Valar, as we find out from The Silmarillion. This episode points in the direction of another archetype, that of the Female Warrior or the Amazon. Certainly, Galadriel is as brave as she is wise. It seems, however, that this experience, of which she later repents, has made her realise the importance of humility. Being one of the most important decision-makers not only in the Elven world but in the whole of Middleearth, she is aware of the dangers of misusing power. After passing the test and rejecting the Ring of Power, she is prepared to abdicate her position as Elven ruler, go into the West and remain known just as Galadriel. Nancy Enright likens her sacrifice to that of her granddaughter, Arwen, who gives up immortality in order to be able to take a mortal spouse, Aragorn.

Like her granddaughter, Arwen, Galadriel is willing to endure personal abdication of power out of love and it is this renunciation that reveals her spiritual and moral strength.[...] Tolkien uses two female characters to emphasize the refusal of the power of endless time in this world, as it moves toward a new age dominated by mortal human beings. (Enright in Bloom 2008:178-182)

Representatives of the archetype of the Holy Mother can be found in the works of Lewis and Rowling, though no figures as imposing as Galadriel appear there. In The Voyage of the Dawn Treader, the travellers find Ramandu's daughter, a fair-haired young woman of radiant beauty, 
awaiting them. We are told that Ramandu is a star who has grown old and has descended upon Earth at the beginning of the end of the world to live with his daughter. If we add that the place where they live is the last island before the end of the world, it becomes clear that these two characters are of some kind of divine origin, which would point to the White Goddess. Every morning father and daughter together sing a song that lasts for the duration of dawn, which may suggest a ritual that causes the sun to rise. We should remember that Galadriel is also known as the Morning Star, another Marian symbol. Unlike Galadriel, who is known by many names, this young woman remains unnamed, even though she is one of the most luminous presences in the series. Caspian X, the king of Narnia, falls in love with Ramandu's daughter and she agrees to marry him, thus becoming queen of Narnia and bearing a son, Prince Rilian. In The Silver Chair we find out that she, too, has been sacrificed, having been killed by the Emerald Witch in the shape of a huge serpent. We may suppose that, being a star's daughter, she would have been a much too powerful protective force for her son and heir and by extension for the whole kingdom. She had to be eliminated in order for the witch's plans to gain control over Narnia through the crown prince to succeed.

Another mother who, willingly and heroically this time, sacrifices herself for her child is Lilly Potter in the Harry Potter series. Although she is killed before the action in the books begins and we do not know very much about her, she remains a strong presence throughout the series, whether in Harry's painful memories and dreams, or by actually appearing to him in the Mirror of Erised in The Philosopher's Stone, or, in The Goblet of Fire, by, together with her husband, saving Harry from certain death. She and James Potter act as support, inspiration and even the trigger for Harry's 
actions, as he tries to be worthy of his parents' sacrifice, to make them proud of him or to avenge their deaths. Lilly is hardly a character we can forget about, especially as we still catch glimpses of her life and personality, as the story unfolds, through the memories other characters have of the Potters. This is enough for the reader to build an image of her as a beautiful, courageous, loving and caring mother to Harry, a faithful friend to Severus Snape, a capable witch in her own right and a perfect match for her husband, a person who does not hesitate to give her life for her son, offering him the ultimate protection - that of selfish, disinterested love. Through her sacrifice we could say that she acquires a certain aura, which entitles her, in my opinion, to join other characters who are embodiments of the Holy Mother archetype.

\subsection{The Good Mother/ the Earth Mother/ Nature}

Tolkien's character Goldberry, wife to Tom Bombadil and along with him one of a pair of ancient nature deities, is evocative of this archetype, though not through her appearance. She is presented as a slender golden-haired woman of uncommon beauty, not as a woman with generous curves to suggest the fertility of nature. However, being known as the "River daughter" and always surrounded by flowers and vegetation, she is in every other way a representation of the force of nature. Goldberry is kind but awe-inspiring and yet the hobbits enjoy her and her husband's hospitality and leave the Old Forest rested and comforted, in a way as a prefiguration of the Company's visit to Lothlórien, just as Goldberry's golden beauty somehow prefigures that of Galadriel.

If the dazzling beauty of Goldberry does not fit within the archetype's common visual representation, short plump Mrs Weasley in 
Harry Potter certainly is a perfect match. Molly Weasley is a strong-willed witch, sometimes snappy, always busy with household chores, but generous and warm; she is a devoted wife to Arthur Weasley and an over-caring mother to her seven children. Harry finds out a lot about the world of wizardry in the Weasleys' shabby house, where he spends part of his school holidays enjoying huge meals and having the feeling of belonging to a family. Mrs Weasley always sends him gifts similar to those she sends to her own children and, in general, acts as a second mother to Harry. As the story progresses, Molly Weasley proves that she is a much more complex character than we may have given her credit for. Once Voldemort returns and the battle between the Death Eaters and Dumbledore's Army begins, she chooses to fight alongside her children, whom she protects ferociously. She proves to be quite a match for Bellatrix Lestrange and an extremely capable witch, thus adhering to the archetype of the Female Warrior and becoming a memorable character in the story.

A similar character appears in C.S. Lewis's The Lion, the Witch and the Wardrobe, although not in human form. Lewis's use of animal personification in The Narnian Chronicles is well known, so it should not be surprising that the embodiment of the Good Mother archtype is Mrs Beaver. The Pevensies find shelter, a most welcome meal and good advice in the house of Mr and Mrs Beaver, who treat them like their own children.

\subsection{The Wise Woman/the archetype of Pallas Athene}

In Tolkien's Lord of the Rings there is one woman who surpasses all others in beauty, as well as wisdom: Arwen Undómiel. We should not compare her to her grandmother, Galadriel, since Arwen is only half-Elven. Rather, they are complementary, with fair Galadriel recalling the Morning 
Star, while dark-haired Arwen is surnamed Evenstar (the Evening Star). Tolkien confessed that he had thought of this character when he was finishing the novel and then tried to introduce her into the story. This would explain why actual references to Arwen are scarce, though her image is present throughout the story, giving strength to Aragorn in times of trouble. Director Peter Jackson found a way around this problem by giving Arwen a more dynamic part to play in the film adaptations and so bringing her closer to the archetype of the Female Warrior. The result is, however, that much of the spectators' attention is directed towards the romance between her and Aragorn rather than towards other themes and events in the story which Tolkien considered more powerful and inspirational to the reader. However, Arwen's sacrifice of her Elvish immortality is retained in the films, too, as an act of love made in full awareness of the fact that the life of mortal men contains happiness as well as sorrow. In the end, as we are told in the Appendices to The Lord of the Rings, Arwen has to bear the pain of her husband's death, and later her own, alone in the forest of Lothlórien. Her sacrifice benefits Frodo, though, to whom she gives her place on the ship that bears the Elves to Valinor, the only place where his inner wounds may be healed.

Two other representatives of the Wise Woman archetype, though in a different key, are immediately evident in Rowling's Harry Potter. One of Harry's two best friends, Hermione Granger, is a well-rounded character who constantly develops and evolves throughout the seven novels of the series. Joanne Rowling confessed that she had conceived the character of Hermione as a caricature of herself at that age. Hermione may start by being a very difficult, bossy and somewhat nerdy girl, but by the time she grows into a teenager these things have changed. Her love of books and of study 
brings her knowledge in the field of wizardry that few adult wizards or witches can boast. This, combined with her native intelligence, love of logic and determination, makes her one of the most accomplished young witches of her age, as Sirius Black remarks. Rowling has repeatedly had to face the accusation that none of the female characters in her novels are central to the story. However, we should consider the fact that the three friends, Harry, Ron and Hermione, are always right in the middle of things, and that the spotlight falls alternately on each of them, as they find the necessary resources to solve the problem at hand. They perceive and treat each other as equals. Nevertheless, as is usually the case with girls, Hermione matures more quickly than her two companions. She may be regarded as an intellectual who initially focused on her mental development, which she considered her priority. However, she is neither a nerd nor an ugly duckling. She has other preoccupations too as she changes from a child into a teenager. She becomes conscious of the way she looks and is pleased to attract the admiration of the Durmstrang champion, which proves her emotional and sexual maturity.

Professor McGonagall demonstrates her allegiance to the Wise Woman archetype from the start through her first name, Minerva, the name of the Roman equivalent of the Greek goddess of wisdom, Athene. She is Dumbledore's right hand and one of the main sources of authority at Hogwarts. She is also a very gifted teacher, though a strict one. There are, however, moments when the reader sees glimpses of her true caring and generous nature, as happens when she and Dumbledore leave Harry as a baby on the Dursleys' doorstep or on the numerous occasions when she looks after the interests of the Hogwarts students. Eliza T. Dresang finds similarities between Minerva McGonagall and Hermione Granger, 
predicting that, Hermione may grow up to be very much like her favourite teacher and even outdo her by being more multidimensional, more socially involved. Another element that connects these two characters is the determination and skill with which they engage in the fight against the dark forces, when the situation calls for this. It is Hermione who comes up with the idea of forming Dumbledore's Army, initially composed of students but eventually joined by almost all the teachers at Hogwarts. In doing this, they become representatives of the archetype of the Female Warrior, thus proving their complexity once more.

Most of the female characters who travel to Lewis's Narnia may be seen primarily as embodiments of the Female Warrior archetype, since visitors from our world are called to Narnia when they are needed to protect the land and its people in accordance with Aslan's wishes. Two of these characters, however, seem closer to the Wise Woman archetype. Their role in the Chronicles is not to do battle, possibly on account of their age, although both are brave enough, but to act as advisers, believers, comforters, loyal friends and even healers. Polly Plummer, Digory's friend and companion in The Magician's Nephew, is a perceptive girl despite being only eleven years old. She is the first person to leave our world through a portal and, together with Digory, witnesses the creation of Narnia by Aslan. Throughout the book she comes across as courageous but more meticulous and cautious than her male counterpart. Although her sound advice is not followed by Digory, she forgives him and remains his faithful friend. She is the one of the pair who sees the empress Jadis of Charn as evil, despite the sweet talk that Jadis uses to bewitch the more gullible Digory. Later, in The Lion, the Witch and the Wardrobe, Edmund Pevensie falls prey to the same evil character, who offers him Turkish Delight to lure him and make him 
betray his siblings. The girl who is aware of the White Witch's evil nature is this time Lucy Pevensie, the youngest of the four Pevensie children. Through her unshaken belief in Aslan, even when her siblings make fun of her, she is shown to be the wisest of the four. For this reason she is able to see Aslan more often than the others. Her kind, generous nature recommends her for the role of healer, a role that she fulfills after Father Christmas gives her a vial of a potion that can cure any wound. Both Polly Plummer and Lucy Pevensie remind us of Hermione Granger, all of them sharing a kind nature, devotion, perceptiveness, common sense and courage in the face of danger.

\subsection{The Female Warrior/the Shieldmaiden/the Amazon}

The character in Tolkien who perceives herself as a shieldmaiden is Éowyn, King Théoden's niece. She has long been regarded as a complex character, one who shows early signs of modernity in Tolkien. Tolkien expert Thomas Shippey states in an interview with Claire E. White:

\footnotetext{
I can only point to the scene in "The Houses of Healing," where there is a careful and sensitive account of what it must have been like for Eowyn, not only trapped at home while the men rode off to war, but trapped with Wormtongue, and watching her uncle fall under his spell. This is a striking and early sensitivity to the theme of female passivity, which people often miss. (White 2002)
}

This is Éowyn's situation when we first encounter her; she is basically a female warrior forced into behaving in line with the damsel in distress archetype. With the arrival of Aragorn, whom she begins to admire as a mighty captain of warriors, she moves towards the archetype that bests suits her nature. Her success in killing the Nazgûl is made possible not only by 
her skill in battle but, ironically, by the very fact that she is a woman. Éowyn subsequently renounces her unrequited love for Aragorn and becomes attracted to Faramir, whom she marries. While many critics see in this Éowyn's decision to take on the more domestic role of a housewife, Nancy Enright believes that it is the beginning of a process of healing for both Faramir and Éowyn. This should involve not only opening their souls to love, but also "a movement from a desire for power and domination [...] to the desire to heal and to help things grow" (Enright in Bloom 2002:183). It also involves, I might add, a movement in the direction of the Wise Woman archetype, a position in which Éowyn finally finds herself after much inner turmoil.

I have already established how characters such as Hermione Granger and Minerva Mc Gonagall in the Harry Potter novels may be seen both as female warriors and as wise women. Yet there is another complex character in the series who evolves from being perceived as a damsel in distress to the archetype of the amazon: Ginny, the youngest of the Weasley siblings. While at the beginning she seems barely present and then is remarked upon only because of her infatuation with Harry Potter, she grows up to become an accomplished young witch, determined and courageous, a valuable member of Dumbledore's Army and, eventually, Harry Potter's wife.

As previously mentioned, the female visitors to Narnia belong to the same archetype of the female warrior. We can enumerate here Susan Pevensie, an accomplished archer, and Jill Pole, bravely fighting the Calormene in The Last Battle. The female protagonist of The Horse and His Boy, Aravis Tarkheena, is more difficult to connect to a particular archetype. The education she received as a young noblewoman and her gift for storytelling might suggest the Wise Woman archetype, while her courage 
and spirit of adventure could help her become a valiant female warrior, especially since there is an indication that she will become queen of Archenland.

\subsection{The Black Goddess/ the Temptress}

The fact that none of the female characters in The Lord of the Rings belong to this archetype demonstrates that Tolkien associated mainly positive features with women, qualities such as "delicacy, creativity, musicality, beauty, unfailing memory, profound wisdom, lasting fidelity", which he also attributed to the Elves, as Stratford Caldecott (The Chesterton Review 2005:118) states.

In The Chronicles of Narnia, by contrast, we find two very impressive and colourful female villains: Jadis, Queen of Charn, also known as the White Witch, and the Queen of the Underland or the Lady of the Green Kirtle. Both are referred to as "Northern Witches" by C.S. Lewis and both are physically attractive, but no other connection is made between them in the books. Jadis appears in The Magician's Nephew as a powerful sorceress, half giant and half Jinn, who, in her desire for power, speaks the Deplorable Word and destroys all life in her world. She manages to find her way into the world of Narnia, witnessing its singing into being by the lion Aslan. As Aslan predicts, she reappears in The Lion, the Witch and the Wardrobe as the White Witch ruling over Narnia as self-imposed queen, condemning the land and its creatures to never-ending winter. In both books Jadis is revealed as a cruel, cold-blooded villain with absolutely no regard for other life than her own. The attributes of the Temptress are revealed when she tries to charm Digory into taking her to his world and when she ensnares Edmund by offering him sweets and the opportunity to rule the 
land by her side. She has a pathological lust for absolute power, which led her to kill her own family together with all the inhabitants of her own world. Her snow-white face and clothes and the perpetual winter to which she dooms Narnia are suggestive of the coldness of her heart. Similarly, the colour green associated with the Lady of the Green Kirtle (in The Silver Chair) may suggest envy directed towards the rightful power-holders, but it is also the colour of the serpent into which she can transform. The Green Lady is an even better deceiver than the White Witch, as she can make people believe quite the opposite of what they know to be true. With her musical laugh she charms both males and females, as happens to Prince Rilian, Eustace and Jill, along with all the creatures of the Underland.

Based on the fact that The Magician's Nephew was actually written five years after The Lion, the Witch and the Wardrobe, Carina RumbergerYanda states that in Jadis Lewis tried to further develop the character of the White Witch, who, like the Lady of the Green Kirtle, was too stereotypical.

By book six, Lewis recognizes the flatness of the White Witch's character. Rather than creating a new temptress, he fills in the incomplete character of the earlier villain. Whereas the Green Lady and the White Witch are collages and reflections of literary villain temptresses familiar to Lewis, Jadis is a culmination of a variety of influences whose nuanced character emerges as a unique individual. (Rumberger-Yanda 2007)

Of the female characters that populate the world of Harry Potter, Bellatrix Lestrange is the one who fits the archetype of the Black Goddess. An attractive and highly skilled witch, she is, however, a fanatical follower of Voldemort. She is very determined in her allegiance, to the point of going to Azkaban rather than betray the Dark Lord. Symbolically, she is killed by 
Molly Weasley, an embodiment of the Good Mother archetype, after trying to strike Ginny Weasley with a killing curse.

\section{Conclusion}

This paper has endeavoured to present some of the many different ways in which female characters are presented in three well-known epic fantasies. I believe I have also demonstrated that there is more than meets the eye about many of these women, and that, behind an appearance of flatness and stereotypy, the attentive reader may find variety, development, original traits and unexpected depth.

\section{References}

Caldecott, Stratford. 2005. "Tolkien's Elvish England” in The Chesterton Review. Fantasy Literature Issue. XXXI, pp. 109-124.

Dresang, Eliza T. 2002. "Hermione Granger and the Heritage of Gender" in The Ivory Tower and Harry Potter. Perspectives on a Literary Phenomenon. Lana E. Whited (Ed.). Columbia: University of Missouri Press, pp. 211-242.

Enright, Nancy. 2008. “Tolkien's Females and the Defining of Power” in J.R.R. Tolkien's The Lord of the Rings. New Edition. Harold Bloom (Ed.). New York: Infobase Publishing, pp. 171-186.

Kirk, E.J. 2005. The Chronicles of Narnia. Beyond the Wardrobe: The Official Guide to Narnia. London: Harper Collins Publishers.

Lewis, Clive Staples. 2005. The Chronicles of Narnia. London: Harper Collins Publishers. Nemoianu, Virgil and Robert Lazu. (Eds.), 2005. J. R. R. Tolkien: credinţă şi imaginaţie. Arad: Hartmann.

Rowling, J.K. 2004. Harry Potter and the Philosopher's Stone. London: Bloomsbury. Rowling, J.K. 2004. Harry Potter and the Chamber of Secrets. London: Bloomsbury. Rowling, J.K. 2004. Harry Potter and the Prisoner of Azkaban. London: Bloomsbury. Rowling, J.K. 2004. Harry Potter and the Goblet of Fire. London: Bloomsbury. Rowling, J.K. 2004. Harry Potter and the Order of the Phoenix. London: Bloomsbury. Rowling, J.K. 2006. Harry Potter and the Half-Blood Prince. London: Bloomsbury. 
Rowling, J.K. 2008. Harry Potter and the Deathly Hallows. London: Bloomsbury.

Rumberger-Yanda, Carina. 2007. "Nothing Yet in Its True Form: Shifting Portrayals of

Female Villains in C. S. Lewis' Chronicles of Narnia" in In Pursuit of Truth. A

Journal of Christian Scholarship [Online]. Available:

cslewis.orghttp://www.cslewis.org/journal/nothing-yet-in-its-true-form-shifting-

portrayals-of-female-villains-in-c-s-lewis-chronicles-of-narnia/view-all/

[Accessed 2015, May 5].

Tolkien, J.R.R. 2007. The Lord of the Rings.London: Harper Collins Publishers.

White, Claire E. 2002. "Talking Tolkien With Thomas Shippey". The Internet Writing

Journal. Available: http://www.writerswrite.com/journal/mar02/talking-tolkienwith-thomas-shippey-3021 [Accessed 2015, May 5]. 